\title{
Structure of Job Profiles in Companies with CMMI-5 Certification in the Colombian Software Industry
}

\author{
Sandra Rojas ${ }^{1}$, Diana Rojas. ${ }^{2}$ \\ ${ }^{1}$ Universidad Nacional de Colombia, Colombia, slrojasm@unal.edu.co \\ ${ }^{2}$ Universidad Nacional de Colombia, Colombia, dmrojasm@unal.edu.co
}

\begin{abstract}
The scope of this research is the work competences of the Software Industry in Colombia, specifically the companies organized under Colombian Federation of Software Industry rated with a high level of quality in the Integrated Capability Maturity Model (level five). It also attempts to identify strengths to be acquired by the professional that makes his functions in the IT area. For this, the aim of this study is to formulate a description of the competency profiles of three software companies through Functional Analysis tool. Likewise, the benefits for organizations and the skills developed by their professionals; to be considered vanguard companies in this sector in the national environment are identified. Finally, is presented an analysis of the labor skills of the companies classified as level five in Colombia and its relationship with the academic profile developed by the "Tuning Latin America" (Tuning) project, with the goal of further developing of management competences in software organizations in Colombia.

Keywords-- Competences, Functional Analysis, Information Technology, Profile position, CMMI.
\end{abstract}

Digital Object Identifier

(DOI):http://dx.doi.org/10.18687/LACCEI2016.1.1.219

ISBN: 978-0-9822896-9-3

ISSN: 2414-6390

$14^{\text {th }}$ LACCEI International Multi-Conference for Engineering, Education, and Technology: "Engineering Innovations for Global Sustainability”, 20-22 July 2016, San José, Costa Rica. 


\title{
Structure of Job Profiles in Companies with CMMI-5 Certification in the Colombian Software Industry
}

\author{
Sandra Rojas ${ }^{1}$, Diana Rojas. ${ }^{2}$ \\ ${ }^{1}$ Universidad Nacional de Colombia, Colombia, slrojasm@unal.edu.co \\ ${ }^{2}$ Universidad Nacional de Colombia, Colombia, dmrojasm@unal.edu.co
}

\begin{abstract}
The scope of this research is the work competences of the Software Industry in Colombia, specifically the companies organized under Colombian Federation of Software Industry rated with a high level of quality in the Integrated Capability Maturity Model (level five). It also attempts to identify strengths to be acquired by the professional that makes his functions in the IT area.

For this, the aim of this study is to formulate a description of the competency profiles of three software companies through Functional Analysis tool. Likewise, the benefits for organizations and the skills developed by their professionals; to be considered vanguard companies in this sector in the national environment are identified.

Finally, is presented an analysis of the labor skills of the companies classified as level five in Colombia and its relationship with the academic profile developed by the "Tuning Latin America" (Tuning) project, with the goal of further developing of management competences in software organizations in Colombia.
\end{abstract}

Keywords-- Competences, Functional Analysis, Information Technology, Profile position, CMMI.

\section{INTRODUCTION}

For Human Resource Management it is essential to build job profiles that fit the needs of organizations. This research aims to know about the skills of professionals working in the field of Software Industry in Colombia, as well as the strengths that must be acquired in the process of lifelong learning [1]. This is where labor skills are set as essential to manage the acquired knowledge and its evolution for people who work in the discipline of Information Technology (IT) [2].

In Colombia there are approximately 2,000 companies related to the software industry including some distributors of hardware and other providers of information services, of these, the $2 \%$ are large companies, $9 \%$ medium, 34\% smaller and $55 \%$ are micro companies [3]. Of the total, there are 244 organizations associated with the Federation of Colombian Software Industry (Fedesoft) [4], institution that is one of the intermediary entities of Software Industry with the Government, which has agreements with universities, other associations and governmental entities and aims for the advancement of the industry through education, quality certifications and other initiatives that promote the welfare of their members.

For companies associated with Fedesoft it is necessary to exercise their activities in ways that meet quality standards, which raise the potential of the sector to a better position in the international environment. One of the quality indicators taken into account at the global level proposed by the Software Engineering Institute (SEI), institution that recognizes and values the most outstanding companies in IT, is the indicator called Integrated Capability Maturity Model (CMMI). Thus, Fedesoft and the Ministry of Information Technology and Communications (MinTIC) have led to large and medium-sized enterprises in the sector to be certified in that model and currently 59 companies in Colombia are certified at levels 3 and 5 of the guidelines of SEI proposed [5].

Given the above, the present study analyzes: the job skills of the nine companies classified as Level Five in Colombia (to September 2014) and the similarities and differences in relation to the academic profile developed by the project "Tuning Latin America" (Tuning), which is developed by a community of Latin American scholars who seek the unification of professional profiles for the Spanish-speaking countries. This in order to deepen on management skills in software organizations in Colombia, useful as a significant reference for other organizations associated with Fedesoft as well as professionals in the field of Systems Engineering and other entities public sector, interested in improving the quality of professional work in this area.

To inquire about the competences of those profiles is necessary: "Focus on knowledge of the tasks, the mission of the profile and the strategic objectives of the organization" [6]. In this sense, the method of Functional Analysis for defining competencies, interviews with experts and relationship to study professional profile "Tuning" allow an approximation of what are the general and disciplinary competences that a qualified professional must have for the development of their work in terms of organizational efficiency and taking into account the implementation of cutting-edge knowledge.

This work is presented in the following chapters, the first one correspond to this introduction; the second chapter includes the purpose and the contextualization of the issue, also the general and specific objectives are described, the study is justified with some background and the theoretical framework; the third discusses the methodological approach on which the research was conducted, collection tools and information organization. In the fourth chapter are the results research, the develop and outcome of the Functional Analysis of the Information Technology (IT) area, comparative analysis of the Tuning project in relation to the information collected and the competitive advantages that are generated in a company that adopts the guidelines proposed by CMMI- 5 
Dev. All of this to describe job profiles with the competencies required by professionals in IT. The fifth and last chapter are the conclusions.

\section{PURPOSE AND CONTEXT}

\section{A. Aim}

The overall objective is to characterize the job profiles competencies of three software companies certified in the Integrated Maturity and Capability Model Level 5 (CMMI-5) in Colombia, and determine a general outline of profiles that can be useful for organizations and the state; to achieve it, the following specific objectives are defined: to analyze three software development organizations in Colombia identifying the advantages that obtaining the CMMI-5 certification; describe profiles of IT area in three Colombian organizations certified with CMMI-5 through Functional Analysis Tool; Identify the skills developed by workers in the IT area, that influence on achieve CMMI-5 certification; Compare scheme profiles charge based on the analysis of labor competencies of these organizations with the results of Tuning Latin America study.

\section{B. Justification}

Organizational analysis based on competencies encourage continuous improvement in the quality and allocation of human resources, generate synergy between job profile and global business strategy, contribute to professional development in a changing environment and making decisions objectively and with homogeneous criteria [7]. Given this argument, the inquiry on competence in these three software companies qualified with CMMI-5 is to identify and analyze the following aspects: the key profile in the area of technology of these organizations; the skills that have been acquired or strengthened with the implementation of CMMI model; activities and results achieved through these skills and how the competences have contributed to that organizations to become consolidated as leaders in the creation and development of software in Colombia.

Some studies were conducted by the government and the Colombian companies [3] [4] [9] and studies to implement the CMMI methodology for small and medium organizations [10], the evaluation of a process of implementing CMMI in a organization [11], implementation based on CMMI model for other areas such as academia and health [12] through a new method, conceptualizing IT capabilities in organizations with a focus on developing products and services in IT [13], and other works concerning on the implementation of CMMI model in different contexts for improving organizational processes and software, investigations such as Moreno [14], Falesi [15], Lukasiewicz, K. and Miller, J. [16] Lopes [17] and works made by big organizations related with skills and job profiles as presented by Ernst and Young [7] specifies that the support organizations are the individuals who work in them and It is necessary to know the skills that require the job profile and the skills that people offer in the labor market.

There are standardization models for handling software recognized worldwide, within these there are The Library Infrastructure Information Technology (ITIL), adopted in the mid-90s, which been origin of several international standards, the most currently known is the ISO/IEC 20000, which covers the IT service management. Other benchmarks on best practices are the Library Information Services Acquisition (ISPL), Application Services Library (ASL), and Dynamic Systems Development Method (DSDM) [3].

All these developments which provide a methodology for the design and software development are of great importance, however, the CMMI has established itself as one of the most recognized by companies and customers around the world. By 2013 there were 1389 companies evaluated with this model, most of them concentrated in China, US and India with 621, 251 and 155 organizations respectively; while in Latin America the countries with more companies valued with CMMI are Mexico, Brazil, Colombia and Argentina with 49, 36, 16 and 9 organizations respectively certified [18].

This model is a reference path for the improvement and evaluation of processes in the development, maintenance and operation of organizational evolution. It consists of best practices aimed at the development and maintenance of the product, and also addresses practices that cover the product lifecycle from conception through delivery and maintenance.

According to the parameters described in the official report of the CMMI-Dev [5] there are three dimensions in which an organization can focus to improve their businesses, these are: the people, methods and procedures and tools and equipment. Consequently, software companies that achieve certification at a Level Five (5) obtain the achievements for all three dimensions.

Therefore, it becomes relevant the integration of the concepts of management skills and job profile, both allows suggest a reference profile, which is complemented by the processes of maturity and capacity proposed by the guidelines of the CMMI.

\section{METHODOLOGICAL DESIGN}

This research is fundamentally qualitative with a deductive approach [19]. A process of observation, classification and association is carried out [20] in order to compare the job profile structure in the area of IT into the companies under investigation. Following these parameters, the information obtained was organized to classify the common patterns of these companies, characterize a job profiles structure and assess competencies in strategic positions of three large companies of Software Industry in Colombia. 
The method of this research is the case study [21], which corresponds to a strategy that focuses on understanding the dynamics that occur within certain conditions, besides allowing relationship among theories and previous studies with empirical reality, in this case, job profiles of the IT area from the perspective of management skills, valid, relevant and verifiable.

Formats data collection of this research are made by us [1], its purpose is to induce the respondent to recognize through quantitative and qualitative factors and empirically valid. Also, considering the "research case studies"; a case study may involve one or more cases and different levels of analysis [23], a sample of some representative companies in the sector was undertaken to identify the common skills required for software engineering professionals, the weighting companies give to the skills proposed by other research as the Tuning Project Latin America [24] and the application of Functional Analysis [25] as a methodology for defining job profiles for main positions found in these organizations.

Companies that have achieved CMMI-5 are organizations specialized in providing IT services at national, regional and international markets. Its purpose is to provide business solutions to its customers through software tools high quality, so are within its main customers: banking organizations, oil, consultant, logistics, industry and others. Being companies providing their services abroad, the CMMI certification is an essential reference for its recognition [26].

In Colombia, by the end of 2014, forty-eight companies were certified with Level Three in the range of CMMI, and only nine companies were certified in CMMI-5: Tata Consultancy Services Limited, TECNOCOM, Productora de Software (PSL S.A), PersonalSoft SAS, MVM Engineering Software S.A, InterGrupo SAS WebServices, International Business Machines (IBM), Heinsohn Business Technology S.A and Asesores de Sistemas Especializados en Software (Asesoftware S.A.S.). To apply the case study, were taken as reference certified at Level 5 companies, leaving aside the global companies like IBM and Tata Consultancy, given its complexity in the organizational structure and the high confidentiality scheme of information that makes them hard get information. On the other hand, the company TECNOCOM, headquartered in Spain, focuses its operation in Colombia in providing telecommunications infrastructure therefore not apply on this analysis of software development in Colombian territory.

Therefore, the sample was performed on six companies, and get collaboration of three of them, which were considered eligible for this study and which are representative in the group of organizations that have a CMMI rating at its highest level, optimized. Worth mentioning that CMMI levels maturity model are: Initial, Managed, Defined, quantitatively managed and optimized. It shows that maturity levels 2 and 3 use the same terms as capacity levels 2 and 3 . This equality in terminology was intentional, since the concepts of maturity levels and levels of capability are complementary. Maturity levels are used to characterize organizational improvements on a set of process areas and capability levels are used to characterize organizational improvements in an individual process area [27].

The names of the companies will not be disclosed at the express request of organizations, in accordance with its corporate policies to this end has been nominated for the letters A, B and C. As such, this sample is sufficient to achieve the purposes of the research: to compare their skills, recognize what is sustained their effort to reach level 5 in the model of the SEI and compare the valuation that give academic competences proposed by Tuning Latin America project. These three companies currently work for both; domestic and international customers, have a payroll between 270 and 500 professionals, are between 20 and 30 years of experience with customers from diverse industry sectors.

For this research two formats where applied, but also were taken into account the relevant aspects that the interviewee said during the interview [28]. Therefore, it was an interview with a flexible orientation, focused, defined by a subject, but where the respondent was able to add what, in his view, it is important. Interviews were conducted with Quality Directors and persons responsible for the certification process CMMI-5. Based on this information, was made the appropriate classification of data, both quantitative and qualitative, which support the development of Functional Analysis methodology, which determines the job profiles by competences for strategic positions of the IT area. At the same time, this information is analyzed to recognize the common cross patterns among these organizations, these patterns happen to be the basis for the development of skills job profiles scheme, the main objective of this research. Also, thanks to the collaboration of these organizations was possible to gain access to manuals functions, which allowed recognize the 3 essential positions of these renowned companies.

Formats data collection have critical information from these organizations, the first, called Presentation format, is related to the generalities of the company, quality certifications obtained, organizational structure, human resource competency management [29], among others aspects.

The second is the Deepening Format where aspects of the certification process were identified before and after CMMI certification was obtained, in terms of general and disciplinary skills, assessment of the skills considered in the study Tuning Latin America and the questions to supply for the Functional Analysis in their steps 1 to 9; these steps are:

1) Select Software companies in Colombia that are considered more competitive in the market, as they have been certified with the highest level of maturity and ability in their software development processes. 
2) Selection of three companies in this group, accounting for $50 \%$ of the total selected as suitable for research. The purpose is to study the key occupational profiles belonging to the area of IT in these three companies.

3) Obtaining the key purpose for each organization through its mission and subsequently respective breakdown proposed methodology.

4) Delimitation of the study to the area of IT, as the central field of the organization, because through it the CMMI-5 certification was achieved.

5) Identification of the Structure job profiles of the IT and its critical roles: executive, architect and analyst.

6) Interview with the person in charge of quality assurance, who was consulted about these important positions, the actions taken, their results and the criteria by which now governs with the CMMI-5 certified.

7) Reconstruction of a set of actions for each position focused on fulfilling the organizational mission, called Skill Units.

8) Reconstruction of the elements of competition, which were grouped into specific skills, in line with the key purpose of the company.

9) Determination of the skills and how they can evidence, according to the above positions, procedures for the area agree with the CMMI-5 model.

With the implementation of the 9 steps of Functional Analysis performed for each of the three Colombian companies, Functional Maps are obtained.

\section{RESEARCH RESULTS}

\section{A. Functional maps}

There are three functional maps produced as result of the adoption of the methodology of Functional Analysis has common characteristics: the main purpose which corresponds to the mission developed for the IT area and consequently the function key. Maps detail units and elements of competence for each of the three profiles: Executive, IT Architect and IT Analyst. It is assigned a number scheme for the competency elements items that are listed in sequence in order to facilitate reading and understanding.

After each functional map is the description of job profiles, the latter are the result of the comparison between functional maps and meta-profile proposed by the Tuning
Project. As was purpose of this research, it was possible to analyze a charge profiles structure composed of three general roles called: Executive, IT Architect and IT Analyst.

From general meta-profile proposed by Tuning, they were assigned the skill units of each role and were contrasted with the job profile of each position of the organizations, resulting in the three job profiles described in the tables below 1,2 and 3.

The Functional Map in the three tables is developed in the following way: each position shows the Main Purpose of the company, then is disaggregated into the following steps of the functional analysis and its found the main organizational function which match with the operational area, then the name of the position (executive, architect and analyst), then the skill units and finally each one of the small tasks that must be executed for achieving one skill unit, called "competency elements", these are detailed into the official document of final work for the Master Degree [1].

TABLE I

FUNTIONAL MAP. EXECUTIVE PROFILE

\begin{tabular}{|c|c|c|c|}
\hline Main purpose & $\begin{array}{c}\text { To manage, promote and develop IT products and services } \\
\text { with world-class human talent and organizational } \\
\text { excellence }\end{array}$ \\
\hline Key Function & \multicolumn{3}{|c|}{ Information Technology Area } \\
\hline Main Position & $\begin{array}{c}\text { Executive } \\
\text { Skill Units } \\
\text { quality of software } \\
\text { products and } \\
\text { services, meet the } \\
\text { expectations of } \\
\text { customers, } \\
\text { following the } \\
\text { procedures and } \\
\text { standards set by the } \\
\text { organization. }\end{array}$ & $\begin{array}{c}\text { Ensure the quality } \\
\text { of } \\
\text { offered by the } \\
\text { organization with } \\
\text { the requirements } \\
\text { established by the } \\
\text { customer. }\end{array}$ & $\begin{array}{c}\text { Coordinate the } \\
\text { working group } \\
\text { and ensure proper } \\
\text { performance of } \\
\text { members of a } \\
\text { project. }\end{array}$ \\
\hline $\begin{array}{c}\text { Competency } \\
\text { elements }\end{array}$ & $1-9$ & $10-23$ & $24-53$ \\
\hline
\end{tabular}

As result of the Functional Analysis is built the profile of the executive position which correspond to: a Professional ensures the quality of products and services information technology offers. Meets customer expectations by adhering to the set standards by the organization to which it belongs. It has the competency to lead working groups ensuring the good performance of each of its members. It is a proactive person who contributes to the development of society and organizations in which it participates, always acting with professional ethics and social responsibility. Apply their knowledge in a way that enables it to identify and solve problems, providing solutions based on Computer Science and Information Technology. Is a person who likes research and is constantly updated, acquiring new skills. It is ready to integrate multidisciplinary teams working in national and international contexts in which assumes with leadership different positions of the profession; Formulates and manages in an effective way projects through planning and organizing resources for its implementation. 
TABLE 2

FUNTIONAL MAP ARQUITECT PROFILE

\begin{tabular}{|c|c|c|}
\hline Main purpose & $\begin{array}{l}\text { To manage, promote and develop IT products and services with } \\
\text { world-class human talent and organizational excellence }\end{array}$ \\
\hline Key Function & \multicolumn{2}{|c|}{ Information Technology Area } \\
\hline Main Position & \multicolumn{2}{|c|}{ Architect } \\
\hline Skill Units & $\begin{array}{l}\text { Support the team } \\
\text { ensuring compliance } \\
\text { with standards, } \\
\text { monitoring guidelines } \\
\text { defined architecture and } \\
\text { the adoption of practices } \\
\text { that result in higher } \\
\text { productivity and quality. }\end{array}$ & $\begin{array}{l}\text { Validate the technical feasibility and } \\
\text { implementation risks of software in the } \\
\text { early stages of the life cycle. } \\
\text { Designing the technical implementation } \\
\text { of software architecture. } \\
\text { Define the structure of the system, its } \\
\text { interfaces and principles, detailed design } \\
\text { and implementation that guide its } \\
\text { organization. }\end{array}$ \\
\hline $\begin{array}{c}\text { Competency } \\
\text { elements }\end{array}$ & $1-12$ & \multicolumn{1}{c}{$13-15$} \\
\hline
\end{tabular}

As a result of the functional map for the position of architect, the profile corresponds to:

IT professional that supports the team, ensuring compliance standards, monitoring guidelines defined by the architecture and the adoption of practices that result in higher productivity and quality. Has the competency to lead working groups and ensures the good performance of each of its members. It is a proactive person who contributes to the development of society and organizations in which it participates, always acting with professional ethics and social responsibility. It is the ideal person to validate the technical feasibility and implementation risks of software in the early stages of its life cycle, designing the technical implementation of software architecture.

Defines the structure of the system, its interfaces, detailed design and implementation. It is ready to integrate multidisciplinary teams working in national and international contexts in which leadership assumes different positions of the profession. Formulates and manages in an effective way projects through planning and organizing resources for its implementation.

TABLE 3

FUNCTIONAL MAP ANALYST PROFILE

\begin{tabular}{|c|l|l|l|}
\hline Main purpose & \multicolumn{2}{|c|}{$\begin{array}{l}\text { To manage, promote and develop IT products and services with } \\
\text { world-class human talent and organizational excellence }\end{array}$} \\
\hline Key Function & \multicolumn{3}{|c|}{ Information Technology Area } \\
\hline Main Position & \multicolumn{3}{|c|}{ Analyst } \\
\hline Skill units & $\begin{array}{l}\text { Design, develop, } \\
\text { test and support } \\
\text { software solutions } \\
\text { that meet customer } \\
\text { requirements. }\end{array}$ & $\begin{array}{l}\text { Design and run tests } \\
\text { planned in the project } \\
\text { development } \\
\text { following the } \\
\text { guidelines of quality } \\
\text { and make feedback } \\
\text { on their performance. }\end{array}$ & $\begin{array}{l}\text { Implement activities } \\
\text { related to the area of } \\
\text { fulfilling } \\
\text { requirements } \\
\text { engineering } \\
\text { processes and } \\
\text { quality parameters } \\
\text { defined in the } \\
\text { organization within } \\
\text { the planned time. }\end{array}$ \\
\hline $\begin{array}{c}\text { Competency } \\
\text { elements }\end{array}$ & $1-9$ & $10-26$ & $27-38$ \\
\hline
\end{tabular}

As a result of the functional map for the Analyst position, the analyst profile corresponds to:
IT professional that designs develops tests and supports software solutions that meet the requirements of customers. Develops projects following the guidelines of quality and making feedback on their performance. It has the competence to work in workgroups. It is a proactive person who contributes to the development of society and organizations in which it participates, always acting with professional ethics and social responsibility. It is the person who designs and implements related to the area of Requirements Engineering, complying with processes and quality parameters defined in the organization, within the planned time activities. It is ready to integrate multidisciplinary teams working in national and international contexts.

\section{B. Methodology for defining job profiles related competences Tuning}

To determine the relationship between job profiles generated from the Functional Analysis and the competences in the study Tuning Latin America, initially the results of evaluations carried out into each company A, B and C regarding the development and strengthening of general and disciplinary competences that the employees obtained during the process of CMMI-5 certification.

Subsequently, a relationship between the general competences of the Tuning study and the skill units of each of the position analyzed in this research is done. Finally, is analyzed disciplinary competences were strengthened further in the process of adopting CMMI practices.

C. Relationship between job profiles and the general competences of the Tuning study in the process of certification CMMI-5

The results of the assessments made by professionals in IT companies analyzed with respect to general competencies identified by the study Tuning Latin America, show what was its application rate to achieve CMMI-5 certified. They are:

In relation with their professional practice, the average obtained in the development of these skills is $96 \%$, professionals considered their skills related with the professional practice were developed to a high degree. Among these, the competences that were strengthened $100 \%$ are: ability to apply knowledge in practice, capacity for abstraction, analysis, synthesis and ability to identify, plan and solve problems.

Professionals considered their ability to learn and continually updated developed to $86 \%$. Similarly, with respect to general skills relating to knowledge in the area of study and the profession, the average development obtained for IT professionals in this competition is $84 \%$. Thus, teamwork skill has been reinforced, and according to research it has been developed a percentage of $83 \%$. The capacities $80 \%$ developed are: capacity to formulate and implement projects, ability to work in international contexts, communication skills in a second language. Meanwhile, a lesser degree of

$14^{\text {th }}$ LACCEI International Multi-Conference for Engineering, Education, and Technology: "Engineering Innovations for Global Sustainability", 20-22 July 2016, San José, Costa Rica. 
development is seen in the ability to organize and plan time, the percentage of development is $74 \%$.

In relation with general skills of social responsibility proposed by the Tuning study, although its development is less with respect to the above, a high application is also observed, its average is $78 \%$. Competition with greater appreciation concerning social responsibility in the effort to become CMMI-5 is the competence of ethical commitment, which professionals consider reinforced in $100 \%$. This consideration is that in each of the organizations has been important loyalty with which workers perform their work inside and outside the organization, which has created a culture of respect for the rules and guidelines of general policies of the company.

Competition with lower valuation, which obtained a weighting of $66 \%$, is the commitment to the socio-cultural environment, because although the organizations are considered active part of society, are mostly focused on the compliance of customer requirements, in service and satisfaction software. They also expressed that is a discipline with technical essence, the sociocultural environment loses some relevance.

\section{Schemes of job profiles regarding general competences of Tuning study}

Executive Position Profile: For the Skill Unit " Supervise that the quality of software products and services, meet the expectations of customers, following the procedures and standards set by the organization " is of great importance that IT executives have the following general competencies Tuning study: problem solving, project management, proper time management and ethical commitment. Also, to "Ensure the quality of support services offered by the organization with the requirements established by the customer" also its necessary to have the skills: apply knowledge to practice, analyze and solve problems. Finally, for the skill unit "Coordinate the working group and ensure proper performance of members of a project" it is necessary that the Executive IT develop the skills of value and respect for diversity and multiculturalism, social responsibility and citizen engagement and commitment to their socio-cultural environment.

For the intermediate position of Architect in these organizations it is denoted that, according to the general competences identified by the Tuning study skills most relevant and which are continually reinforced by the structure of each of the projects are: deep analytical skills, application knowledge to the design of the system structure, ability to solve problems even in international contexts, research capacity to manage projects with proper time management, teamwork competition. All of this with ethical commitment.

Analyst position for an organization that has the CMMI-5 certified are highly valued competencies concerning the exercise of the profession. Professionals must have highly developed skills in analysis, abstraction and synthesis, as well as those corresponding to apply knowledge appropriately to solving problems and continually updated. For this position it is important that workers have the ability to work together and develop the ability to habituate to international contexts given the competitive environment of these organizations. It is also crucial ethical commitment.

\section{E. Relationship of job profiles with the general competences of the Tuning study in the process of certification CMMI-5}

The results of the evaluation of the disciplinary competencies of the Tuning project reinforced by professionals in the process of the CMMI-5 certification are: $96 \%$ innovation skills and the $80 \%$ for management and leadership competences.

Also, competences that obtained higher qualification in quality and fundamentals of information are: "Apply knowledge of computer science, information technologies and organizations to develop information solutions". Also, due to the rigor that requires adherence to CMMI model, organizations weighted competences as "Conceive, design, develop and operate IT solutions based on engineering principles and quality standards" applied and further developed by $100 \%$.

On the field of innovation, it shows that these companies, that are in a highly competitive environment, they must be companies that adopt cutting-edge practices, techniques that allow them to have higher yields, be more efficient and save time on rework due to errors detected in the system. The average assessment is $94 \%$, for this reason are considered organizations that capture professionals with high innovative capacity, but also this innovation is reinforced by the policy of these companies as they try to always go forward in the assimilation of new technologies enabling them to develop their business.

About the field of management and leadership they are considered solid companies, many of them with international recognition and established foreign markets, the skill more strengthened in the certification process was to "understand and apply ethical, legal, economic and financial concepts in decision-making and IT project management", with a percentage of $86 \%$ and scored lower rating, with $74 \%$, is the competition of "play different positions in IT projects, in multidisciplinary and multicultural contexts: local and globalized". This is because one of those three organizations has only domestic market, Colombia, while the other two have costumers in Latin America and North America.

For the three positions is important to have specific skills in these areas, even for analysts who want to climb within these organizations, they must develop skills in the area of management and leadership that enables them to improve in their positions. 
It is important to mention not only that these organizations seek professionals with development of appropriate skills for the competitive sector in which they are, but also, it is fundamental for these professionals to be in a successful structured organization, because their skills are used and have the optimal environment for continuing discover and develop their skills, and thus, respond to multiple demands of human talent to provide quality solutions through competence management [30].

Similarly, it is necessary to have into account that the competences do not remain static over time, especially in a world that is constantly changing, driven by the rapid evolution of science, the use of information technology and communications, biotechnology research, development of genetics, electronics and new materials science [31]. This whole set of factors requires knowledge about which skills should develop the individual to cope with changes in the work environment, therefore there is a general need to acquire knowledge, not only of a specific discipline, but also the necessity to have tools appropriate from different disciplines to change adapt [32].

\section{CONCLUTIONS}

Among the advantages that organizations can recognize by adopting a certification model on best practices for software development such as CMMI methodology they are: greater understanding on the implementation of projects through reliable and verifiable information; best execution plans projects according to a more realistic view and permanent monitoring; minimizing rework; better product quality; a pleasant working environment and better organized.

The experts identify competencies that are critical to achieving CMMI-5 certification like: adopting development standards; have techniques and test methodologies and implement them properly; ensure that the stages of the project as well as documentary and follow-up support are carried out rigorously through quantitative techniques that enable them to make objective decisions, also, another core competence is to systematize information for IT solutions so that it becomes the organizational "lessons learned" and be part of knowledge management applied by these organizations to become a competitive advantage over companies that do not have yet this type of organizational background. Important general skills in this organizational learning are proper time management and teamwork, to ensure dynamics results in a highly competitive environment.

As a result of this research, was analyzed the structure of job profiles of IT area into organizations with CMMI-5, from which three positions were identified: Executive, architect and analyst: For each, through the methodology of functional analysis, were obtained: functional maps, and the corresponding profile.
Organizations are aligned with the competences raised by the study Tuning Latin America. Within the general skills are of great importance for these companies related with the pursuit of the profession, application of IT knowledge and social responsibility. In the latter the most relevant to them is the ethical commitment in the development of their profession. However, they consider that all skills are essential to be a comprehensive professional. Within its organizational policy selection and training all these competencies, in particular those technical skills and application of knowledge and tacitly other skills such as the ability to update and adapt to multicultural environments, environmental care and commitment to the socio-cultural environment.

Disciplinary skills with the highest score in the evaluation are: applying quality standards in the development and evaluation of solutions and apply knowledge of computer science, technology information and organizations to develop solutions. This without leaving behind all other competences for these companies they have been instrumental in implementing the model, such as innovation capacity and application of systemic thinking to problem solving.

Companies not only value these skills in their professional but also, become the epicenter of skills development, as they provide workers necessary tools to continue evolving both: in knowledge and in their position profile.

\section{REFERENCES}

[1] D. Rojas, Estructura de perfiles de cargo en las empresas con certificación CMMI-5 de la Industria de Software en Colombia. Universidad Nacional de Colombia. Sede Bogotá. 2015.

[2] Drucker, Administración para el futuro, Gestión y empresa. 2010.

[3] MinTIC, Visión estratégica del sector de software y servicios asociados: plan de mercadeo y ventas regionalizado del sector en Colombia. 2013.

[4] MinTIC, Estudio de salarios y profesiones del sector de software y TI de Colombia. 2012

[5] SEI, CMMI for Development, Version 1.3. Improving processes for developing better products and services. Estados Unidos, Software Engineering Institute: 482. 2010.

[6] A. Enríquez, El concepto de competencias. De las competencias al centro de evaluación. Universidad del Valle: pp 20. 2009.

[7] Ernst and Young, C. Manual del director de recursos humanos. Gestión por competencias. pp20. 2011

[8] MinCIT, Programa de transformación productiva. 2010.

[9] MinTIC, Informe sectorial de la industria de software y servicios asociados de Colombia. 2012.

[10] H. Arboleda, H. P. A. "Metodología para implantar el Modelo Integrado de Capacidad de Madurez en grupos pequeños y emergentes". Estudios Gerenciales. pp 177-188. 2013.

[11] W. Yépes, and C. Torres, "Mejoras al proceso de planificación de proyectos de software usando el Modelo de Madurez de Capacidad Integrado (CMMI)" Compendium, 16 (30): 27-47 Universidad Centroccidental Lisandro Alvarado. Venezuela. 2013

[12] H. Luna, F. Álvarez and R. Mendoza. "Management Model for Curriculum Design based on Software Engineering Practices". Revista Electrónica de Investigación Educativa 17(3), 61-78. 2015.

[13] R. Kishore, M. Swinarski, E. Jackson, and R. Rao. A Quality-Distinction Model of IT Capabilities: Conceptualization and Two-Stage Empirical Validation Using CMMI Processes. IEEE Transactions on Enginieering Managment, 59 (3), 457. 2012

[14] A.Moreno, M. Sánchez-Segura, F. Medina-Dominguez, and G. Cuevas, "Process Improvement from an Academic Perspective: How Could

$14^{\text {th }}$ LACCEI International Multi-Conference for Engineering, Education, and Technology: "Engineering Innovations for Global Sustainability", 20-22 July 2016, San José, Costa Rica. 
Software Engineering Education Contribute to CMMI Practices?". IEEE Software 90-97. 2014

[15] D. Falessi, M. Shaw, and K. Mullen, Achieving and Maintaining CMMI Maturity Level 5 in a Small Organization. IEEE SOFTWARE pp. 80-86, 2014

[16] K. Lukasiewicz and J. Miller, "Improving agility and discipline of software development with the Scrum and CMMI." IET The Institution of Engineering and Technology Software. Gdansk University of Technology. Poland. 6(5). 416-422. 2012

[17] I. Lopes, R. Moreira, and M. Vieira, "Lessons Learnt in the Implementation of CMMI Maturity Level 5". IEEE Software Eighth International Conference on the Quality of Information and Communications Technology. pp. 47-56. 2012

[18] Y. González, N. Hernández and J. Medina, "Análisis del estado actual de certificaciones CMMI-DEV ver. 1.3 año 2013 y 2014, a nivel Mundial y en México" Instituto Tecnológico de Apizaco, Departamento de Sistemas y Computación, Apizaco, Tlaxcala: 14. 2014

[19] G. Briones, Métodos y técnicas de investigación para las ciencias sociales: El proyecto de investigación. México, Trillas. 2003

[20] P. Carlile, "The cycles of theory building in Managment Research." Harvard Business School Working Paper 05: 057. 2005.

[21] K. Eisenhard, "Building Theories from case study research." Academy of Management Review 14: 532-550. 1989.

[22] B. Glaser, "The Discovery of Grounded Theory: Strategies of qualitative research." Wiedenfeld and Nicholson. 1967.

[23] Yin B. Glaser, "The Discovery of Grounded Theory: Strategies of qualitative research." Wiedenfeld and Nicholson. 1967.

[24] J. Contreras, et al, Tuning América Latina. Educación Superior en América Latina: reflexiones y perspectivas en informática. Bilbao, España, Universidad de Deusto. 2013

[25] OIT- ChileValora, Guía de apoyo para la elaboración del Análisis Funcional. Guía de apoyo para la elaboración del Análisis Funcional. OIT. Santiago, Chile, OIT. 2012

[26] M. Koznia, "Applying the CMMI model in software process improvement". 22nd International DAAAM Symposium, 22(1) Vienna, Austria. 2011.

[27] J. Ulibarri, El Modelo de Capacidad de Madurez Integrado y sus diferentes disciplinas y representaciones. Departamento de Ingeniería en Sistemas Computacionales. Escuela de Ingeniería., Universidad de las Américas, Puebla. Tesis de Ingeniería en Sistemas Computacionales. 2012.

[28] R. López and J. Estrada, "La entrevista cualitativa como técnica para la investigación en Trabajo Social." Margen 61: 19. 2011.

[29] A. Cowling. La esencia de la administración de personal y las relaciones industriales, Prentice Hall Hispanoamérica. 1997

[30] H. Hamel, Competence based on competition, Wilwy \& Sons. 2013.

[31] J. Núñez. "La ciencia y la tecnología como procesos sociales. Lo que la educación científica no debería olvidar." Sala de lecturas CTS+I de la OEI. 2001

[32] A. Catalano. Diseño curricular basado en normas de competencia laboral: conceptos y orientaciones metodológicas. Buenos Aires, Banco Interamericano de Desarrollo. 2004

$14^{\text {th }}$ LACCEI International Multi-Conference for Engineering, Education, and Technology: "Engineering Innovations for Global Sustainability”, 20-22 July 2016, San José, Costa Rica. 